\title{
Calf health from birth to weaning. III. housing and management of calf pneumonia
}

\author{
Ingrid Lorenz ${ }^{{ }^{*}}$, Bernadette Earley², John Gilmore ${ }^{3}$, Ian Hogan ${ }^{4}$, Emer Kennedy ${ }^{5}$ and Simon J More ${ }^{1,6}$
}

\begin{abstract}
Calfhood diseases have a major impact on the economic viability of cattle operations. A three part review series has been developed focusing on calf health from birth to weaning. In this paper, the last of the three part series, we review disease prevention and management with particular reference to pneumonia, focusing primarily on the pre-weaned calf. Pneumonia in recently weaned suckler calves is also considered, where the key risk factors are related to the time of weaning. Weaning of the suckler calf is often combined with additional stressors including a change in nutrition, environmental change, transport and painful husbandry procedures (castration, dehorning). The reduction of the cumulative effects of these multiple stressors around the time of weaning together with vaccination programmes (preconditioning) can reduce subsequent morbidity and mortality in the feedlot. In most studies, calves housed individually and calves housed outdoors with shelter, are associated with decreased risk of disease. Even though it poses greater management challenges, successful group housing of calves is possible. Special emphasis should be given to equal age groups and to keeping groups stable once they are formed. The management of pneumonia in calves is reliant on a sound understanding of aetiology, relevant risk factors, and of effective approaches to diagnosis and treatment. Early signs of pneumonia include increased respiratory rate and fever, followed by depression. The single most important factor determining the success of therapy in calves with pneumonia is early onset of treatment, and subsequent adequate duration of treatment. The efficacy and economical viability of vaccination against respiratory disease in calves remains unclear.
\end{abstract}

Keywords: Calf health, Disease prevention, Disease management, Suckler calf weaning, Castration, Dehorning, Housing, Pneumonia

\section{Introduction}

Calfhood diseases have a major impact on the economic viability of cattle operations, due to the direct costs of calf losses and treatment and the long-term effects on performance [1]. Furthermore, calf health was prioritised as one of the most important animal health issues facing the Irish livestock industry in a recent expert Policy Delphi study conducted on behalf of Animal Health Ireland (AHI [2]. As part of ongoing AHI work, a group of experts was commissioned to provide evidence-based advice on calf health and disease management to Irish farmers, agricultural advisers and veterinary practitioners. As an initial step, a review series on calf health from birth to weaning has been developed, specifically

\footnotetext{
* Correspondence: Ingrid.Lorenz@ucd.ie

'Herd Health and Animal Husbandry, UCD School of Veterinary Medicine,

University College Dublin, Belfield, Dublin 4, Ireland Full list of author information is available at the end of the article
}

to provide a scientific evidence base to underpin advisory tools on calf health, and to identify gaps in current knowledge to be filled with targeted research. Even though the envisaged output will be specific for Irish husbandry systems, the scope of the reviews should make them useful for the same purpose elsewhere. The reviews cover both suckler and dairy calf management. However, due to the differences in the nature of these systems, some topics will deal mainly or exclusively with either dairy or suckler calves.

This paper is the last in a three part review series, which collectively focuses on calf health from birth to weaning. The first and second parts focus on general aspects of disease prevention [3] and the management of diarrhoea [4] in pre-weaned calves, respectively. In the current paper, we review housing and ventilation as well as prevention and management of pneumonia in recently weaned suckler calves and young dairy calves.
C Biomed Central 
There is a very distinct difference in the epidemiology of pneumonia of suckler calves and dairy calves. Most of the risk factors for pneumonia in young dairy calves are identical with what has been discussed in the first paper of this series [3], whereas additional risk factors for suckler calves will be discussed here.

\section{Housing and ventilation \\ Housing systems}

Calves are born with functional thermoregulatory mechanisms. Therefore, healthy calves are readily able to deal with outdoor temperatures as long as they receive adequate amounts of energy and are provided with a dry, well-bedded and draft-free shelter [5]. The lower critical temperature, at which additional energy is needed for heat production, lies in the range of $10-15^{\circ} \mathrm{C}$ for calves in the first two weeks of life, declining with age to approximately $6-10^{\circ} \mathrm{C}$ in older calves, and is highly dependent on air speed $[5,6]$. The quality of bedding material is crucial for the amount of heat loss via conduction in calves lying down [6]. Deep straw bedding is superior to other bedding material in its efficacy as an insulator [6,7] and can provide a high 'nesting score' which has a preventive effect against calf respiratory disease in naturally ventilated calf barns [8].

Individual housing of dairy calves, either indoors or outside, is generally linked with improved calf health. There is long-term recognition of the benefit to dairy calf health of outdoor housing in hutches, especially for the prevention of diarrhoea and respiratory disease [9]. Hutches have been associated with lower morbidity and mortality in dairy calves [10-12]. No significant difference in either average daily gain, incidence of scours or pneumonia in the first two weeks of life was observed when comparing indoor and outdoor rearing in individual pens, whereby the indoor facilities have not been used for calf rearing before [13]. However, caring for calves in outdoor hutches can be uncomfortable in adverse weather conditions [10]. If calves are housed individually in naturally ventilated calf barns, solid dividers on the side of pens, together with a high 'nesting score', lower the risk for respiratory disease [8]. European legislation prohibits solid walls in individual calf pens and, while it allows calves to be kept individually for the first 8 weeks of life, it encourages group housing for animal welfare reasons (Council Directive 2008/119/ $\mathrm{EC})$.

There have been mixed reports on the impact of group housing of calves, both indoors and outside, on calf health. A number of authors have reported higher morbidity [14-19] and mortality [12] among grouphoused pre-weaned dairy calves compared to individual housing. In contrast, two surveys report no difference in mortality between calves in group housing or individual housing $[20,21]$. In one out of two similar experiments Kung et al. found that fewer days of medication were needed in group-housed calves than in calves housed individually in hutches. However, the authors discuss the possibility that superior disease detection in individual housing could account for this finding [22]. Mortality was highest in larger calf groups ( $\geq 7$ calves [23]) and tended to be lower in small groups compared with either individual housed calves or calves kept in large groups [19]. Calves in stable groups had significantly higher daily live weight gains than those in dynamic groups (where new calves were continuously introduced to and exited group housing). The prevalence of both diarrhoea and respiratory disease was more than twice as high among calves in dynamic compared to stable groups [24]. Grouping calves of similar age lowers the risk of respiratory disease compared to groups with wider age differences [25]. A higher incidence of respiratory disease but a lower incidence of diarrhoea has been identified when calves were reared in indoor groups compared with outdoor groups [26]. A review of group housing of dairy calves with different feeding systems concluded that group housing increases the risk of infection, especially in larger groups and thus requires more skills and poses more challenges to management [27].

In summary, there are a high number of experimental studies and surveys dealing in various ways with aspects of individual and group housing, as well as outdoor and indoor rearing, with sometimes contradicting results. Overall, outdoor individual hutches appear superior to indoor housing, and individual housing/small group housing appears superior to large group housing with regards to calf health.

\section{Ventilation}

Inadequate ventilation of calf barns increases the risk of disease due to a build up of high levels of humidity, noxious gases, dust and bacterial content [28]. Ammonia levels of less than $10 \mathrm{ppm}$ are recommended [28], however, concentrations of $5 \mathrm{ppm}$ already lead to adverse effects on the respiratory system in piglets [29]. Ammonia concentrations are enhanced by the accumulation of urine and faeces, which emphasises the need for regular cleaning and provision of dry bedding, together with adequate ventilation.

To prevent adverse conditions, at least 4 air changes per hour are needed in winter and up to 40 in summer [30]. Natural ventilation is achieved through wind and buoyancy in monopitch or duopitch houses, given that adequate air outlets (ridge opening: $5 \mathrm{~cm}$ width for every $3 \mathrm{~m}$ width of the building) and inlets (eave openings: at least half the space of ridge openings) [31], as well as sufficient difference in height between the openings is provided (not less than $1.5 \mathrm{~m}$, but preferably 2.5 
m) [6]. Recommended air space per calf is not less than $6 \mathrm{~m}^{3}$ up to 6 weeks and $10 \mathrm{~m}^{3}$ up to 12 weeks of age [6].

Problems can arise in naturally ventilated calf barns in cold and damp wintry conditions, when it can be impossible to keep relative humidity below an acceptable level of $85 \%$ [6]. Additionally, ventilation is often compromised by closing of air inlets in an attempt to prevent cold stress for the calves. If calves are housed in individual pens indoors, the barn climate often does not reflect the microclimate in the pens. Ventilation is impaired with an increasing numbers of solid panels surrounding the calf (solid walls in the back or front of the pen, top covers), leading to an increase in airborne microbes [8].

\section{Risk factors for disease in recently weaned suckler calves Weaning management of the suckler calf}

In suckler herds, calves generally remain with cows at pasture until they are weaned, usually between 5 and 9 months of age. In addition to removal from the cow, the weaning procedure may be compounded by other stressors occurring around the same time, e.g. change of diet (grass and milk to conserved feed with or without concentrates), change of environment (outdoors to indoors). Non-integrated systems often combine weaning with additional stressors such as transportation and marketing, prior to entry into feedlots [32]. Alterations in calf behaviour [33,34], hormonal mediators of stress $[35,36]$ and consequently impaired immune function [37-41] are evident post-weaning. Furthermore, weaning is considered to be a predisposing factor to pneumonia in recently weaned suckler calves [42-44] and reducing the cumulative effects of multiple stressors around the time of weaning results in a less marked stress response. This strategy, combined with vaccination programmes and feeding concentrates pre-weaning (preconditioning), reduces subsequent morbidity and mortality in the feedlot [45] and provided the rationale for the 'Animal welfare, recording and breeding scheme for suckler herds' (Suckler Welfare Scheme) in Ireland [46].

Delaying housing of calves post-weaning reduces the magnitude of the stress response [41]. Also, calves supplemented with concentrate prior to weaning had a lesser reduction in some immune cells (i.e. $\gamma \delta \mathrm{T}$ lymphocytes), started consuming meal faster when housed indoors and spent more time lying down (rather than standing and walking) post-weaning compared with non-supplemented calves. Concentrate supplementation of suckler calves is often advocated as a means of reducing weaning stress in calves through familiarisation to a palatable feed [47] and has been reported to decrease morbidity in feedlots [48]. Management practices aiming at reducing stress at weaning include the use of anti-suckling devices (nose-clips) for a period prior to weaning $[34,49,50]$, fence-line contact between calf and dam post-weaning $[33,49,51,52]$ and a combination of both practices before complete separation [53]. The benefit of two-stage weaning with nose-clips and fence-line weaning on calf welfare has been questioned in a recent study, with no overall reduction of distress behaviours in weaned calves, but rather redistribution of these behaviours on the days post-attachment of noseclip and on the days post-weaning [54].

\section{Painful procedures}

There are aspects of cattle production such as castration, disbudding and dehorning which cause pain and stress for the animal. Dehorning or disbudding of horned cattle is a mandatory requirement in many countries to reduce the risk of injuries to humans or other animals $[55,56]$. Cortisol and behavioural response to disbudding is significantly smaller than to amputation dehorning, implying that the latter is more painful [57]. Castration of male cattle is a routine procedure used in some husbandry systems to facilitate handling and modify carcass quality. It elicits physiological stress by increasing plasma cortisol concentrations, inflammatory reactions, pain associated behaviour, suppression of immune function and a reduction in performance [58-62]. Burdizzo castration causes a lower cortisol response than either surgical or rubber ring castration [63]. Physiological stress as measured by cortisol levels and inflammatory reactions (acute-phase proteins, scrotal swelling and surface skin temperature) are lower in 1.5 month old calves compared to older calves after Burdizzo castration [61].

Pharmacological methods (local anaesthesia, systemic analgesia using non-steroidal anti-inflammatory drugs, xylazine sedation) are available that are highly beneficial in alleviating the acute pain caused by castration, dehorning or disbudding $[57,63]$. National legislation regarding animal welfare and regulations concerning the usage of these drugs by veterinarians or producers vary between countries and have to be taken into account.

\section{Calf pneumonia}

\section{Aetiology and epidemiology}

Pneumonia in pre-weaned calves is a multi-factorial disease involving a well known group of viruses (bovine herpesvirus 1, BoHV1; bovine respiratory syncytial virus, BRSV; parainfluenza 3 virus, PI3) and bacteria (Mycoplasma bovis, Pasteurella multocida, Mannheimia haemolytica, Histophilus somni), as well as calf-related and environmental risk factors. Bovine viral diarrhoea virus (BVDV) appears to play an important role, both in terms of immunosuppression and synergistic effects with other pathogens and also as a primary pneumopathogen [64]. Accumulating evidence has been found 
in recent years that bovine coronavirus plays a role in bovine respiratory disease [65].

Many aspects of respiratory disease in cattle have recently been reviewed [66], including issues specific to beef [67] and dairy [68] calves.

A number of factors are known to modify the risk of pneumonia in calf populations. Prior to weaning, singlesuckled beef calves outdoors are at the lowest risk of pneumonia [67]. Outbreaks can occur due to sudden inclement weather [69]. However, if suckler calves are born and reared indoors, the incidence of pneumonia can be considerable [70]. In the period following weaning, pneumonia has a high prevalence in weaned beef calves. A large national survey of the US beef industry found that $14.4 \%$ of cattle placed in US feedlots acquire the disease [71]. The population wide-characteristics of weaned cattle of high respiratory disease risk include animals being of light weight, cattle from multiple origins, previous history of disease and cattle experiencing long journeys before arriving at a feedlot [72].

According to recent US data, respiratory disease is responsible for nearly a quarter of pre-weaned calf deaths and nearly half of weaned calf deaths in dairy replacement heifers [73]. Dairy calf rearing management and facilities vary widely between farms. Therefore, each of the previously mentioned risk factors at calf and environment level has to be considered when faced with an outbreak of calf pneumonia. Additional factors identified to increase pneumonia risk in housed calves include shared airspace with older animals, overcrowding, and power-washing of calf facilities while calves are still present [68].

\section{Recognition}

Cases of calf pneumonia may not be detected by the animal keeper, but are more likely to be missed than misdiagnosed, as Sivula et al. have shown that keeper diagnosis is only $56 \%$ sensitive but $100 \%$ specific [74].

Early signs of calf pneumonia include elevated respiratory rate, fever, serous nasal discharge and at the most mild depression or inappetence [75]. Since early treatment is the most important factor that prevents treatment failure, recognition at this stage would be preferable. The feasibility of daily measurement of the body temperature in high-risk periods is highly dependent on the housing system and handling facilities. When treatment is based on rectal temperature, thresholds of $40-40.3^{\circ} \mathrm{C}$ for feedlot cattle and $39.7^{\circ} \mathrm{C}$ for calves have been suggested [28]. If measurement of the body temperature is not practical, early recognition and the success of treatment relies on good observational skills of the animal keeper. Evaluating calves for treatment using a screening system, such as the calf respiratory scoring chart developed at the University of Wisconsin, which is based on rectal temperature, character of nasal discharge, eye or ear appearance and presence of coughing, has been recommended for dairy calves $[68,76]$. Apley [77] suggests that treatment should be instituted on recognition of depression with undifferentiated fever, with depression being the more important of these two parameters.

\section{Diagnostic tests}

The value of diagnostic tests in calf pneumonia is somewhat limited due to the multifactorial nature of the disease and the uncertainty if the pathogens recovered from samples are causative to the disease [78]. Most outbreaks can be successfully managed using the principles for treatment described above, and diagnostic tests cannot replace the examination of management practices and facility design in cases of recurrent outbreaks [28].

If animals are selected for ante-mortem sampling they should be in the early stages of the pneumonic process, before treatment, and should show typical signs of the process affecting the group [79]. Nasal swabs should only be used to identify upper respiratory tract viruses [79]. Deep nasopharyngeal swabs, positive for M. haemolytica and M. bovis, have been demonstrated to be representative of isolates present in the lungs [80]. Samples obtained from transtracheal wash and/or bronchoalveolar lavage (BAL) can be used for virology, bacteriology, cytology and parasitology [79]. However, the presence of bacterial isolates in nasopharyngeal swabs or tracheal and/or bronchoalveolar lavage needs to be interpreted with caution, in light of recent studies in which $63 \%$ of healthy calves were culture positive for bovine bacterial pathogens from BAL fluid [78]. In one study, a high level of pathogens was found in the lungs of calves on arrival at feedlots [81]. However, in another, the lungs were virtually sterile at the time of slaughter [82]. Bacteria may be more likely to frequent the lung during high stress periods due to impairment of the mucociliary escalator mechanism [81].

Postmortem examination of untreated animals in the early stages of calf pneumonia can be useful, whereas repeatedly treated animals with chronic pneumonia are usually of little diagnostic value [79]. Faeces should be examined for lungworm larvae, even though false negatives may occur if the animals are sampled before adult lungworm become patent [83].

\section{Treatment}

Antibiotic treatment of bacterial pneumonia must be sufficient in duration and, most crucially, early enough to prevent lesions forming that may resist both therapy and regeneration of normal lung parenchyma [28]. The emphasis should be on early treatment and first treatment success in cases of calf pneumonia since the outcome for those animals that fail to respond successfully to first treatment is poor. Typically, one third to two 
thirds of animals that do not respond to initial therapy are permanently affected or lost [84].

The effectiveness of metaphylaxis (defined as mass medication of all animals on arrival in the feedlot) in reducing morbidity rates associated with pneumonia in feedlots is variable [72]. A recent meta-analysis of North American studies estimated a decrease in mortality and morbidity of $2 \%$ and $26 \%$, respectively for animals that received antimicrobial treatment on arrival in the feedlot. The average daily weight gain was $0.11 \mathrm{~kg}$ higher in these animals in comparison with calves not receiving metaphylactic treatment [85].

The use of antimicrobials for prevention (prophylaxis or metaphylaxis) of calf pneumonia has to be seen in the context of increasing pressure on the veterinary profession to promote prudent use of antibiotics, noting that indiscriminate use of antibiotics promotes the selection and subsequent proliferation of antibiotic-resistant strains of bacteria [86]. The European Parliament recently called for a review of current practices of prophylactic use of antimicrobials [87].

Non-steroidal anti-inflammatory drugs (NSAIDs) have shown to reduce pyrexia [88-91], clinical signs $[89,90]$, and lung pathology [90-92], and improve average daily weight gains [92] in calves with respiratory disease compared to untreated calves or calves only treated with antimicrobials. Other studies, however, have not found significant differences between treatment groups $[93,94]$. The cost-efficiency of additional anti-inflammatory therapy in bovine respiratory disease is uncertain [28].

It has been suggested that pneumonic animals should be isolated in appropriate facilities [42]. However, there is little experimental evidence to quantify the benefits and it may lead to practical difficulties.

\section{Specific prevention (vaccination)}

The efficacy and economical viability of vaccination against respiratory disease in calves remains uncertain. Although substantial relevant literature is available, a consensus, underpinned by robust scientific findings, has not yet been achieved. The evaluation of vaccine efficacy, and the interpretation of trial results, is complicated by the nature of bovine respiratory disease, and in particular the multitude of pathogens and environmental stressors that contribute to disease development. Additionally, the disease pattern of pneumonia in calves can vary under a variety of husbandry systems, as a consequence of differing challenges at different points in the rearing period.

Modified live vaccines, inactivated vaccines, or subunit vaccines are available for most of the major pathogens. For the most part, relevant research has focused on the ability of these vaccines to trigger an immune response or to decrease clinical disease and pathogen shedding in challenge trials. Although field trials are needed to provide conclusive evidence of vaccine efficacy under field conditions [28], few of these have been reported. In a very recent paper, where a field trial was conducted, Windeyer [95] could find no beneficial effect of vaccination with a multivalent respiratory vaccine in a large population of young dairy calves with a low incidence of failure of passive transfer.

Substantial data are available on pneumonia in feedlot cattle, predominantly from the USA. These data provide useful insights, albeit for different husbandry systems, of the impact of multiple stressors on recently weaned suckler calves. The feedlot studies clearly indicate that vaccination provides best results when carried out in healthy animals and prior to the exposure to defined stressful events, such as weaning, marketing, transportation and associated changes in environment. Vaccination together with further management measures (preconditioning) in suckler calves before weaning has been shown to be beneficial on the performance of these animals after arrival in feedlots. However, in these studies the benefit of vaccination and management procedures cannot be assessed independently [45]. Perino and Hunsaker [96] conducted a review of field trials to assess the efficacy of mono- or multivalent vaccination against bovine respiratory disease without preconditioning. Using outcomes of morbidity and mortality in feedlot cattle, these authors identified 9 studies with positive and 13 studies with neutral or negative outcomes.

Early studies with formalin-inactivated experimental Bovine Respiratory Syncytial Virus vaccines demonstrated enhancement in disease severity after subsequent infection [97]. Meanwhile the safety and efficacy of modified live and inactivated BRSV vaccines have been demonstrated in experimental challenge trials, whereby reduced clinical disease and lung lesions have been found in most [98-100] but not all [101] trials. Monovalent BRSV vaccines have rarely been tested in field trials. Van Donkersgoed et al [102] tested a modified live BRSV vaccine in eight different scenarios in calves and yearlings and found only significant reduction of cases of bovine respiratory disease in 2 groups. However, all animals were comingled throughout the trials, which suggests that the development of herd immunity could have affected the apparent efficacy of the vaccine.

Young calves do not produce specific antibodies after vaccination in the presence of maternally derived immunity. For this reason, it is commonly believed that maternal antibodies can interfere with the efficacy of vaccination [103]. To overcome this issue, research in recent years has focused on the use of the mucosal immune system for vaccination. Intranasal vaccination against BRSV proved effective in challenge studies in calves without maternal antibodies [104-107]. In calves with maternal antibodies against BRSV, protective effect 
of intranasal vaccination compared to an unvaccinated control group was confirmed in two studies $[106,108]$. However, Ellis et al. [105] could not prevent clinical disease and lung lesions in calves with or without maternal antibodies that were challenged 4.5 months after intranasal vaccination with a modified-live virus vaccine.

Depending on virus virulence and host resistance, Bovine Herpes Virus 1 infection can cause clinical pictures from severe classical Infectious Bovine Rhinotracheitis (IBR) to no clinical signs at all. Regardless, infection will lead to latency in the host. In relation to calf pneumonia, it is important to consider the immunosuppressive effect of BoHV1 infection as well as BoHV1 reactivation [109]. Conventional BoHV-1 vaccines containing modified live virus are very effective, inducing both humoral and cellular immune responses [110]. However, they can establish latency and can be reactivated with adverse effects on pregnant cows or young calves in contact with the vaccinated animals. Inactivated vaccines, on the other hand, are safe but less efficacious as they only stimulate humoral immunity [109]. Gene-deleted ( $\left.\mathrm{gE}^{-}\right)$modified live virus and inactivated marker vaccines, to distinguish vaccination from field virus infection, have been developed and are commercially available [111]. Vaccination of newborn calves, especially in the presence of maternal antibodies, poses the same challenges as described for BRSV vaccination and is in the focus of current research [111]. Intranasal vaccination of seronegative newborn calves decreases clinical signs in a challenge trial [107]. However, the situation is complicated by the potential for establishment of seronegative latent carriers in calves with specific maternal antibodies through field virus infection as well as through vaccination with modified-live vaccines [112,113]. In Europe, the use of conventional vaccines is prohibited in some countries. Further, in countries with existing eradication programmes, regulations regarding vaccination need to be considered [114].

Vaccines against the major bacterial pathogens involved in bovine respiratory disease (Pasteurella multocida, Mannheimia haemolytica, Histophilus somni) can decrease clinical signs in challenge models but are rarely tested in monovalent form in field trials [115]. Aubry et al. [116] were unable to identify any decrease in treatments for respiratory disease in young dairy calves vaccinated with a modified-live Mannheimia haemolytica and Pasteurella multocida vaccine.

\section{Conclusions}

Pneumonia is a significant cause of morbidity and mortality in calves, both during the pre-weaning period and shortly following weaning. A range of events are linked with increased disease risk, including weaning management, painful procedures, housing systems and ventilation and effective preventive measures have been demonstrated. The management of pneumonia in calves is reliant on a sound understanding of aetiology and of relevant risk factors and of effective approaches to diagnosis and treatment.

\section{Acknowledgements}

The authors from Animal Health Ireland's Technical Working Group (TWG) on Calf Health would like to thank the remaining colleagues of the TWG for their valuable input:

Mary Canty (Centre for Veterinary Epidemiology and Risk Analysis, UCD School of Veterinary Medicine, University College Dublin, Belfield, Dublin 4, Ireland; Department of Agriculture, Fisheries and Food, Kildare St, Dublin 2, Ireland), Charles Chavasse (Pfizer Animal Health, Riverwalk, National Digital Park, Citywest Business Campus, Dublin, Ireland), John Fagan (Department of Agriculture, Fisheries and Food, Regional Veterinary Laboratory, Coosan, Athlone, Co. Westmeath, Ireland), Richard J. Fallon (Castleknock Green, Castleknock, Dublin, Ireland), Liam Gannon (Volac Ireland, Church St, Killeshandra, Co. Cavan, Ireland), John F. Mee (Animal and Grassland Research and Innovation Centre, Teagasc Moorepark, Fermoy, Co. Cork, Ireland).

\section{Author details}

'Herd Health and Animal Husbandry, UCD School of Veterinary Medicine, University College Dublin, Belfield, Dublin 4, Ireland. ${ }^{2}$ Animal and Bioscience Research Department, Teagasc, Animal and Grassland Research and Innovation Centre, Grange, Dunsany, Co. Meath, Ireland. ${ }^{3}$ Emlagh Lodge Veterinary Centre, Elphin, Co. Roscommon, Ireland. ${ }^{4}$ Department of Agriculture, Fisheries and Food, Regional Veterinary Laboratory, Knockalisheen, Limerick, Ireland. ${ }^{5}$ Animal and Grassland Research and Innovation Centre, Teagasc Moorepark, Fermoy, Co. Cork, Ireland. ${ }^{6}$ Centre for Veterinary Epidemiology and Risk Analysis, UCD School of Veterinary Medicine, University College Dublin, Belfield, Dublin 4, Ireland.

\section{Authors' contributions}

$I L, B E, J G, I H$ and EK drafted the manuscript and compiled the literature. All authors made substantial inputs to the review, critically discussed the progressing manuscript and approved the final manuscript.

\section{Conflict of interest statement}

None of the authors of this paper has a financial or personal relationship with other people or organisations that could inappropriately influence or bias the content of the paper. The Technical Working Group includes employees of Pfizer Inc. (CC) and Volac Ireland (LG); these companies played no role in the design, development or journal submission of this review series.

Received: 12 July 2011 Accepted: 21 October 2011 Published: 21 October 2011

\section{References}

1. Donovan GA, Dohoo IR, Montgomery DM, Bennett FL: Calf and disease factors affecting growth in female Holstein calves in Florida, USA. Prev Vet Med 1998, 33:1-10.

2. More SJ, McKenzie K, O'Flaherty J, Doherty ML, Cromie AR, Magan MJ: Setting priorities for non-regulatory animal health in Ireland: results from an expert Policy Delphi study and a farmer priority identification survey. Prev Vet Med 2010, 95:198-207.

3. Lorenz I, Mee JF, Early B, More SJ: Calf health from birth to weaning. I. General aspects of disease prevention. Ir Vet J 2011, 64:10.

4. Lorenz I, Fagan J, More SJ: Calf health from birth to weaning. II. Management of diarrhoea in pre-weaned calves. Ir Vet J 2011, 64:9.

5. Davis CL, Drackley JK: The development, nutrition, and management of the young calf Ames, lowa: lowa State University Press; 1998.

6. Webster J: Calf husbandry, health and welfare London, UK: Collins; 1984.

7. Inglis JS, Robertson A: The measurement of heat loss through floors. Vet Rec 1953, 65:875-876. 
8. Lago A, McGuirk SM, Bennett TB, Cook NB, Nordlund KV: Calf respiratory disease and pen microenvironments in naturally ventilated calf barns in winter. J Dairy Sci 2006, 89:4014-4025.

9. Davis LR, Autrey KM, Herlich H, Hawkins GE Jr: Outdoor individual portable pens compared with conventional housing for raising dairy calves. $J$ Dairy Sci 1954, 37:562-570.

10. McKnight DR: Performance of newborn dairy calves in hutch housing Can J Anim Sci 1978, 58:517-520.

11. Waltner-Toews D, Martin SW, Meek AH: Dairy calf management, morbidity and mortality in Ontario Holstein herds. III. Association of management with morbidity. Prev Vet Med 1986, 4:137-158.

12. Waltner-Toews D, Martin SW, Meek AH: Dairy calf management, morbidity and mortality in Ontario Holstein herds. IV. Association of management with mortality. Prev Vet Med 1986, 4:159-171.

13. Jorgenson $\sqcup$, Jorgensen NA, Schingoethe DJ, Owens MJ: Indoor versus outdoor calf rearing at three weaning ages. J Dairy Sci 1970, 53:813-816.

14. Maatje K, Verhoeff J, Kremer WD, Cruijsen AL, van den Ingh TS: Automated feeding of milk replacer and health control of group-housed veal calves. Vet Rec 1993, 133:266-270.

15. Olsson S-O, Viring S, Emanuelson U, Jacobsson S-O: Calf diseases and mortality in Swedish dairy herds. Acta Vet Scand 1993, 34:263-269.

16. Hanekamp WJA, Smits AC, Wierenga HK: Open versus closed barn and individual versus group-housing for bull calves destined for beef production. Livest Prod Sci 1994, 37:261-270

17. Svensson C, Lundborg K, Emanuelson U, Olsson S-O: Morbidity in Swedish dairy calves from birth to 90 days of age and individual calf-level risk factors for infectious diseases. Prev Vet Med 2003, 58:179-197.

18. Svensson C, Liberg P: The effect of group size on health and growth rate of Swedish dairy calves housed in pens with automatic milk-feeders. Prev Vet Med 2006, 73:43-53.

19. Svensson C, Hultgren J, Oltenacu PA: Morbidity in 3-7-month-old dairy calves in south-western Sweden, and risk factors for diarrhoea and respiratory disease. Prev Vet Med 2006, 74:162-179.

20. James RE, McGilliard ML, Hartman DA: Calf mortality in Virginia Dairy Herd Improvement herds. J Dairy Sci 1984, 67:908-911.

21. Wells SJ, Dargatz DA, Ott SL: Factors associated with mortality to 21 days of life in dairy heifers in the United States. Prev Vet Med 1996, 29:9-19.

22. Kung L, Demarco S, Siebenson LN, Joyner E, Haenlein GF, Morris RM: An evaluation of two management systems for rearing calves fed milk replacer. J Dairy Sci 1997, 80:2529-2533.

23. Losinger WC, Heinrichs AJ: Management practices associated with high mortality among preweaned dairy heifers. J Dairy Res 1997, 64:1-11.

24. Pedersen RE, Sørensen JT, Skjøth F, Hindhede J, Nielsen TR: How milk-fed dairy calves perform in stable versus dynamic groups. Livest Sci 2009, 121:215-218.

25. Gulliksen SM, Jor E, Lie Kl, Loken T, Akerstedt J, Osteras O: Respiratory infections in Norwegian dairy calves. J Dairy Sci 2009, 92:5139-5146.

26. Earley B, Murray M, Farrell JA, Nolan M: Rearing calves outdoors with and without calf jackets compared with indoor housing on calf health and live-weight performance. Irish J Agr Food Res 2004, 43:59-67.

27. Hepola H: Milk feeding systems for dairy calves in groups: effects on feed intake, growth and health. Appl Anim Behav Sci 2003, 80:233-243.

28. Woolums AR, Ames TR, Baker JC: The bronchopneumonias (respiratory disease complex of cattle, sheep, and goats). In Large Animal Internal Medicine.. 4 edition. Edited by: Smith BP. Mosby, Elsevier; 2009:602-643.

29. Hamilton T, Roe J, Webster A: Synergistic role of gaseous ammonia in etiology of Pasteurella multocida-induced atrophic rhinitis in swine. $J$ Clin Microbiol 1996, 34:2185-2190.

30. Bates DW, Anderson JF: Calculation of ventilation needs for confined cattle. J Am Vet Med Assoc 1979, 174:581-589.

31. Bates DW, Anderson JF: Environmental design for a total animal health care system. Bov Pract 1984, 19:4-20.

32. Duff GC, Galyean ML: Board-invited review: recent advances in management of highly stressed, newly received feedlot cattle. J Anim SCi 2007, 85:823-840.

33. Price EO, Harris JE, Borgwardt RE, Sween ML, Connor JM: Fenceline contact of beef calves with their dams at weaning reduces the negative effects of separation on behavior and growth rate. J Anim Sci 2003, 81:116-121.

34. Haley DB, Bailey DW, Stookey JM: The effects of weaning beef calves in two stages on their behavior and growth rate. J Anim Sci 2005, 83:2205-2214
35. Lefcourt AM, Elsasser TH: Adrenal responses of Angus $\times$ Hereford cattle to the stress of weaning. J Anim Sci 1995, 73:2669-2676.

36. Blanco $M$, Casasús I, Palacio J: Effect of age at weaning on the physiological stress response and temperament of two beef cattle breeds. Animal 2009, 3:108-117.

37. Hickey MC, Drennan M, Earley B: The effect of abrupt weaning of suckler calves on the plasma concentrations of cortisol, catecholamines, leukocytes, acute-phase proteins and in vitro interferon-gamma production. J Anim Sci 2003, 81:2847-2855.

38. Arthington JD, Eicher SD, Kunkle WE, Martin FG: Effect of transportation and commingling on the acute-phase protein response, growth, and feed intake of newly weaned beef calves. J Anim Sci 2003, 81:1120-1125.

39. Lynch E, Earley B, McGee M, Doyle S: Characterisation of physiological and immunological responses in beef cows to abrupt weaning and subsequent housing. BMC Vet Res 2010, 6:37.

40. Lynch E, Earley B, McGee M, Doyle S: Effect of abrupt weaning at housing on leukocyte distribution, functional activity of neutrophils, and acute phase protein response of beef calves. BMC Vet Res 2010, 6:39.

41. Lynch EM, McGee M, Doyle S, Earley B: Effect of post-weaning management practices on physiological and immunological responses of weaned beef calves. Irish J Agr Food Res 2011.

42. Callan RJ, Garry FB: Biosecurity and bovine respiratory disease. Vet Clin North Am Food Anim Pract 2002, 18:57-77.

43. Snowder GD, Van Vleck LD, Cundiff LV, Bennett GL: Bovine respiratory disease in feedlot cattle: environmental, genetic, and economic factors. $J$ Anim Sci 2006, 84:1999-2008.

44. Snowder G: Genetics, environment and bovine respiratory disease. Anim Health Res Rev 2009, 10:117-119.

45. Cole NA: Preconditioning calves for the feedlot. Vet Clin North Am Food Anim Pract 1985, 1:401-411.

46. Department of Agriculture, Fisheries and Food: Suckler herds welfare scheme 2008-2012. [http://www.agriculture.gov.ie/ farmerschemespayments/sucklerherdswelfarescheme2008-2012]

47. Lardy GP, Maddock TD: Creep feeding nursing beef calves. Vet Clin North Am Food Anim Pract 2007, 23:21-28.

48. Myers SE, Faulkner DB, Ireland FA, Parrett DF: Comparison of three weaning ages on cow-calf performance and steer carcass traits. $J$ Anim Sci 1999, 77:323-329.

49. Siegford JM, Buskirk DD, Sharra MK: Behaviour of beef calves weaned by traditional, fenceline and two-step methods. J Anim Sci 2007, 90(Suppl 1):365.

50. Boland HT, Scaglia G, Swecker WS, Burke NC: Effects of alternate weaning methods on behavior, blood metabolites, and performance of beef calves. The Professional Animal Scientist 2008, 24:539-551.

51. Stookey JM, Schwartzkopt-Genswin KS, Watts JM: Effects of remote and contact weaning on behaviour and weight gain of beef calves (Abstract). J Anim Sci 1997, 75:83.

52. Burke NC, Scaglia G, Boland HT, Swecker WS: Influence of two-stage weaning with subsequent transport on body weight, plasma lipid peroxidation, plasma selenium, and on leukocyte glutathione peroxidase and glutathione reductase activity in beef calves. Vet Immunol Immunopathol 2009, 127:365-370.

53. Newberry RC, Swanson JC: Implications of breaking mother-young social bonds. Appl Anim Behav Sci 2008, 110:3-23.

54. Enríquez DH, Ungerfeld R, Quintans G, Guidoni AL, Hötzel MJ: The effects of alternative weaning methods on behaviour in beef calves. Livest Sci 2010, 128:20-27.

55. Vowles B: Bruising of carcasses cost us millions. J Agr Victoria 1976, 74:388-392.

56. Marshall BL: Bruising in cattle presented for slaughter. N Z Vet J 1977, 25:83-86.

57. Stafford K, Mellor DJ: Dehorning and disbudding distress and its alleviation in calves. Vet J 2005, 169:337-349.

58. Molony $\mathrm{V}$, Kent JE, Robertson IS: Assessment of acute and chronic pain after different methods of castration of calves. Appl Anim Behav Sci 1995, 46:33-48.

59. Fisher AD, Crowe MA, O'Nuallain EM, Monaghan ML, Prendiville DJ, O'Kiely P, Enright WJ: Effects of suppressing cortisol following castration of bull calves on adrenocorticotropic hormone, in vitro interferongamma production, leukocytes, acute-phase proteins, growth, and feed intake. J Anim Sci 1997, 75:1899-1908. 
60. Earley B, Crowe MA: Effects of ketoprofen alone or in combination with local anesthesia during the castration of bull calves on plasma cortisol, immunological, and inflammatory responses. J Anim Sci 2002, 80:1044-1052.

61. Ting STL, Earley B, Veissier I, Gupta S, Crowe MA: Effects of age of Holstein-Friesian calves on plasma cortisol, acute-phase proteins, immunological function, scrotal measurements and growth in response to Burdizzo castration. Animal Science 2005, 80:377-386.

62. Pang WY, Earley B, Sweeney T, Pirani S, Gath V, Crowe MA: Effects of banding or burdizzo castration of bulls on neutrophil phagocytosis and respiratory burst, CD62-L expression, and serum interleukin-8 concentration. J Anim Sci 2009, 87:3187-3195.

63. Stafford KJ, Mellor DJ: The welfare significance of the castration of cattle: A review. N Z Vet J 2005, 53:271-278.

64. Ridpath J: The contribution of infections with bovine viral diarrhea viruses to bovine respiratory disease. Veterinary Clinics of North America Food Animal Practice 2010, 26:335-348.

65. Saif LJ: Bovine respiratory coronavirus. Vet Clin North Am Food Anim Pract 2010, 26:349-364.

66. Cooper VL, Brodersen BWE: Bovine respiratory disease. Vet Clin N Am: Food Anim Pract 2010, 26:1-426.

67. Stokka GL: Prevention of respiratory disease in cow/calf operations. Vet Clin N Am: Food Anim Pract 2010, 26:229-241.

68. Gorden PJ, Plummer P: Control, management, and prevention of bovine respiratory disease in dairy calves and cows. Vet Clin North Am Food Anim Pract 2010, 26:243-259.

69. Wiseman A, Selman IE, Pirie HM, Harvey IM: Letter: Pneumonia in singlesuckled calves. Vet Rec 1976, 98:409-410.

70. Assié S, Seegers H, Beaudeau F: Incidence of respiratory disorders during housing in non-weaned Charolais calves in cow-calf farms of Pays de la Loire (western France). Prev Vet Med 2004, 63:271-282.

71. USDA: Part III: Health Management and Biosecurity in U.S. Feedlots, 1999. USDA:APHIS:VS, CEAH, National Animal Health Monitoring System. Fort Collins, CO. \#N336.1200. 2000.

72. Nickell JS, White BJ: Metaphylactic antimicrobial therapy for bovine respiratory disease in stocker and feedlot cattle. Vet Clin North Am Food Anim Pract 2010, 26:285-301.

73. USDA: Dairy 2007, Part II: Changes in the U.S. Dairy Cattle Industry, 1991-2007. USDA-APHIS-VS, CEAH. Fort Collins, Colorado, USA, \#N481.0308. 2008.

74. Sivula NJ, Ames TR, Marsh WE, Werdin RE: Descriptive epidemiology of morbidity and mortality in Minnesota dairy heifer calves. Prev Vet Med 1996, 27:155-171.

75. Stöber M: Krankheiten der Atmungsorgane, des Zwerchfells und der Brustwand. In Innere Medizin und Chirurgie des Rindes.. 4 edition. Edited by: Dirksen G, Gründer HD, Stöber M. Parey; 2002:271-356.

76. McGuirk SM: Disease management of dairy calves and heifers. Vet Clin North Am Food Anim Pract 2008, 24:139-153.

77. Apley M: Bovine respiratory disease: pathogenesis, clinical signs, and treatment in lightweight calves. Vet Clin North Am Food Anim Pract 2006, 22:399-411.

78. Angen O, Thomsen J, Larsen LE, Larsen J, Kokotovic B, Heegaard PMH, Enemark JMD: Respiratory disease in calves: microbiological investigations on trans-tracheally aspirated bronchoalveolar fluid and acute phase protein response. Vet Microbiol 2009, 137:165-171.

79. Cooper VL, Brodersen BW: Respiratory disease diagnostics of cattle. Vet Clin North Am Food Anim Pract 2010, 26:409-416.

80. Godinho KS, Sarasola P, Renoult E, Tilt N, Keane S, Windsor GD, Rowan TG, Sunderland SJ: Use of deep nasopharyngeal swabs as a predictive diagnostic method for natural respiratory infections in calves. Vet Rec 2007, 160:22-25

81. Allen JW, Viel L, Bateman KG, Rosendal S, Shewen PE, Physick-Sheard P: The microbial flora of the respiratory tract in feedlot calves: associations between nasopharyngeal and bronchoalveolar lavage cultures. Can J Vet Res 1991, 55:341-346

82. Yates WD, Kingscote BF, Bradley JA, Mitchell D: The relationship of serology and nasal microbiology to pulmonary lesions in feedlot cattle. Can J Comp Med 1983, 47:375-378.

83. Panuska C: Lungworms of ruminants. Vet Clin North Am Food Anim Pract 2006, 22:583-593.
84. Sweiger SH, Nichols MD: Control methods for bovine respiratory disease in stocker cattle. Vet Clin N Am: Food Anim Pract 2010, 26:261-271.

85. Wileman BW, Thomson DU, Reinhardt CD, Renter DG: Analysis of modern technologies commonly used in beef cattle production: conventional beef production versus nonconventional production using metaanalysis. J Anim Sci 2009, 87:3418-3426.

86. Mateu $E$, Martin $M:$ Why is anti-microbial resistance a veterinary problem as well? J Vet Med B Infect Dis Vet Public Health 2001, 48:569-581.

87. European Parliament resolution of 12 May 2011 on antibiotic resistance. 2011 [http://www.europarl.europa.eu/sides/getDoc.do? type $=$ TA\&reference $=P 7-T A-2011-0238 \&$ language $=E N]$.

88. Verhoeff J, Wierda A, van Vulpen C, Dorresteijn J: Flunixin meglumine in calves with natural bovine respiratory syncytial virus infection. Vet Rec 1986, 118:14-16.

89. Guzel M, Karakurum MC, Durgut R, Mamak N: Clinical efficacy of diclofenac sodium and flunixin meglumine as adjuncts to antibacterial treatment of respiratory disease of calves. Aust Vet J 2010, 88:236-239.

90. Selman I, Allan E, Gibbs H, Wiseman A, Young W: Effect of antiprostaglandin therapy in experimental parainfluenza type 3 pneumonia in weaned, conventional calves. Vet Rec 1984, 115:101-105.

91. Lockwood PW, Johnson JC, Katz TL: Clinical efficacy of flunixin, carprofen and ketoprofen as adjuncts to the antibacterial treatment of bovine respiratory disease. Vet Rec 2003, 152:392-394.

92. Friton GM, Cajal C, Ramirez-Romero R: Long-term effects of meloxicam in the treatment of respiratory disease in fattening cattle. Vet Rec 2005, 156:809-811

93. Scott P: Field study of undifferentiated respiratory disease in housed beef calves. Vet Rec 1994, 134:325-327.

94. Scott PR, McGowan M, Sargison ND, Penny CD, Lowman BG: Use of tilmicosin in a severe outbreak of respiratory disease in weaned beef calves. Aust Vet J 1996, 73:62-64.

95. Windeyer $C$ : Vaccination and risk factors for bovine respiratory disease in dairy heifer calves. University of Guelph; 2010.

96. Perino $L$, Hunsaker $\mathrm{BD}$ : A review of bovine respiratory disease vaccine field efficacy. Bov Pract 1997, 31:59-66.

97. Gershwin L: Bovine respiratory syncytial virus infection: immunopathogenic mechanisms. Anim Health Res Rev 2007, 8:207-213.

98. West K, Petrie L, Konoby C, Haines DM, Cortese V, Ellis JA: The efficacy of modified-live bovine respiratory syncytial virus vaccines in experimentally infected calves. Vaccine 1999, 18:907-919.

99. Ellis J, West K, Konoby C, Leard T, Gallo G, Conlon J, Fitzgerald N: Efficacy of an inactivated respiratory syncytial virus vaccine in calves. J Am Vet Med Assoc 2001, 218:1973-1980.

100. Ellis JA, West KH, Waldner C, Rhodes C: Efficacy of a saponin-adjuvanted inactivated respiratory syncytial virus vaccine in calves. Can Vet J 2005, 46:155-162.

101. Salt JS, Thevasagayam SJ, Wiseman A, Peters AR: Efficacy of a quadrivalent vaccine against respiratory diseases caused by BHV-1, PI3V, BVDV and BRSV in experimentally infected calves. Vet J 2007, 174:616-626.

102. Van Donkersgoed J, Janzen $E$, Townsend H, Durham P: Five field trials on the efficacy of a bovine respiratory syncytial virus vaccine. Can Vet J 1990, 31:93-100.

103. Cortese VS: Neonatal immunology. Vet Clin North Am Food Anim Pract 2009, 25:221-227.

104. Ellis J, Gow S, West K, Waldner C, Rhodes C, Mutwiri G, Rosenberg H: Response of calves to challenge exposure with virulent bovine respiratory syncytial virus following intranasal administration of vaccines formulated for parenteral administration. J Am Vet Med Assoc 2007, 230:233-243.

105. Ellis JA, Gow SP, Goji N: Response to experimentally induced infection with bovine respiratory syncytial virus following intranasal vaccination of seropositive and seronegative calves. J Am Vet Med Assoc 2010, 236:991-999.

106. Vangeel I, Antonis AFG, Fluess M, Riegler L, Peters AR, Harmeyer SS: Efficacy of a modified live intranasal bovine respiratory syncytial virus vaccine in 3-week-old calves experimentally challenged with BRSV. Vet J 2007, 174:627-635

107. Xue W, Ellis J, Mattick D, Smith L, Brady R, Trigo E: Immunogenicity of a modified-live virus vaccine against bovine viral diarrhea virus types 1 and 2, infectious bovine rhinotracheitis virus, bovine parainfluenza-3 
virus, and bovine respiratory syncytial virus when administered intranasally in young calves. Vaccine 2010, 28:3784-3792.

108. Woolums AR, Brown CC, Brown JC, Cole DJ, Scott MA, Williams SM, Miao C: Effects of a single intranasal dose of modified-live bovine respiratory syncytial virus vaccine on resistance to subsequent viral challenge in calves. Am J Vet Res 2004, 65:363-372.

109. Jones C, Chowdhury S: Bovine herpesvirus type 1 (BHV-1) is an important cofactor in the bovine respiratory disease complex. Vet Clin North Am Food Anim Pract 2010, 26:303-321.

110. Endsley JJ, Quade MJ, Terhaar B, Roth JA: BHV-1-Specific CD4+, CD8+, and $\gamma \delta$ T Cells in Calves Vaccinated with One Dose of a Modified Live BHV-1 Vaccine. Viral Immunol 2002, 15:385-393.

111. van Drunen Littel-van den Hurk S: Rationale and perspectives on the success of vaccination against bovine herpesvirus-1. Vet Microbiol 2006, 113:275-282.

112. Lemaire M, Meyer G, Baranowski E, Schynts F, Wellemans G, Kerkhofs P, Thiry E: Production of bovine herpesvirus type 1-seronegative latent carriers by administration of a live-attenuated vaccine in passively immunized calves. J Clin Microbiol 2000, 38:4233-4238.

113. Lemaire M, Weynants V, Godfroid J, Schynts F, Meyer G, Letesson JJ, Thiry E: Effects of bovine herpesvirus type 1 infection in calves with maternal antibodies on immune response and virus latency. J Clin Microbiol 2000, 38:1885-1894

114. EFSA: Definition of a BoHV-1-free animal and a BoHV-1- free holding, and the procedures to verify and maintain this status. Annex to the EFSA Journal 2006, 311:1-65.

115. Confer AW: Use of biologics in the prevention of infectious diseases, Mannheimia (Pasteurella) haemolytca, Pasteurella multocida, and Histophilus somni (Haemophilus somnus). In Large Animal Internal Medicine.. 4 edition. Edited by: Smith BP. Mosby, Elsevier; 2009:1607-1610.

116. Aubry P, Warnick LD, Guard CL, Hill BW, Witt MF: Health and performance of young dairy calves vaccinated with a modified-live Mannheimia haemolytica and Pasteurella multocida vaccine. J Am Vet Med Assoc 2001, 219:1739-1742.

doi:10.1186/2046-0481-64-14

Cite this article as: Lorenz et al.: Calf health from birth to weaning. III.

housing and management of calf pneumonia. Irish Veterinary Journal 2011 64:14

\section{Submit your next manuscript to BioMed Central and take full advantage of:}

- Convenient online submission

- Thorough peer review

- No space constraints or color figure charges

- Immediate publication on acceptance

- Inclusion in PubMed, CAS, Scopus and Google Scholar

- Research which is freely available for redistribution

Submit your manuscript at www.biomedcentral.com/submit 